\title{
Eulophia obtusa (Orchidaceae: Epidendroideae: Cymbideae) an addition to the flora of Bangladesh, with notes on its ecology and conservation status
}

\author{
Md Sharif Hossain Sourav ${ }^{1}$, Ronald Halder ${ }^{2}$, Pankaj Kumar ${ }^{3}$ \& André Schuiteman ${ }^{4}$
}

Summary. Little published information exists about Eulophia obtusa, a showy and distinctive species previously recorded from North India and Nepal. It is here reported from Bangladesh for the first time. The population occurring in Bangladesh may represent a distinct colour form, with pure white instead of bright yellow sepals and petals as in previous records. A species growing in seasonally waterlogged grassland, its only known site in Bangladesh has already been destroyed for agricultural development. No reliable data on its present day occurrence in India and Nepal could be obtained. However, the most recent of only three collections in the Kew Herbarium dates from 1902, which suggests that it is quite a rare species. It must be assessed as critically endangered (CR) in Bangladesh, according to the IUCN Red Listing criteria.

Key Words. endangered, habitat loss, Orthochilus.

\section{Introduction}

During a field trip in June 2008, in the Barind area of Rajshahi $\left(24^{\circ} 22^{\prime} \mathrm{N}, 88^{\circ} 36^{\prime} \mathrm{E}\right)$ in west Bangladesh (Map 1), the second author photographed an unusual wild orchid with grass-like leaves and attractive white and rose-red flowers growing in tall grasslands surrounded by agricultural fields. These grasslands remain water-logged during the rainy season for around two months. On 27 June 2014, the first author revisited the site to explore the plant's habitat at Godagari. About 20 flowering individuals of the orchid were found growing among grasses, herbs, shrubs and climbers. Based on studies of the protologue and herbarium material, including the type, this striking orchid was identified as the poorly known Eulophia obtusa (Lindl.) Hook. f., which apparently is a new record for Bangladesh.

\section{Taxonomic treatment}

The genus Eulophia R. Br. includes about 230 terrestrial or sometimes lithophytic species, and is distributed worldwide in the tropics and subtropics, but predominantly in Africa and continental Asia (Pridgeon et al. 2009). Of these, 10 species are distributed in Bangladesh including the new record of Eulophia obtusa (Govaerts et al. 2016). Based on molecular and morphological studies, Martos et al. (2014) suggested that, in order to maintain the monophyly of Eulophia, the genus Orthochilus Hochst. ex A. Rich., should be reinstated, a position supported by Bone et al. (2015). This proposal is still under debate (Chase et al. 2015). If it is accepted, the number of species for genus Eulophia will be reduced to 164 , but with essentially an unchanged distribution area. There would be no change in the generic position of E. obtusa.

Eulophia obtusa (Lindl.) Hook. f. (Hooker 1890: 3); Duthie (1906: 129, t. 111). (Fig. 1)

Cyrtopera obtusa Lindl. (Lindley 1833: 190); Graphorkis obtusa (Lindl.) Kuntze (1891: 662); Lissochilus obtusus (Lindl.) Schltr. (Schlechter 1919: 260). Type: India, Northwest India (Uttarakhand), on the banks of Tonse R. near Deokhutul, J. F. Royle s.n. (K000078320) (K!).

Eulophia campanulata Duthie (1902: 39). Syntypes: India, Dehra Dun, at Karwapáni, W. Bell s.n. (n.v.) and P. W. Mackinnon's collector s.n. (n.v.); N

Accepted for publication 8 March 2017. Published online 20 April 2017

1 Department of Environmental Science and Management, North South University, Dhaka, Bangladesh. e-mail: nature.sourav@gmail.com

2 Baikal Teal Production, Dhaka, Bangladesh.

3 Kadoorie Farm and Botanic Garden, Lam Kam Road, Tai Po, New Territories, Hong Kong.

4 Royal Botanic Gardens, Kew, Richmond, Surrey, TW9 3AB, UK. 

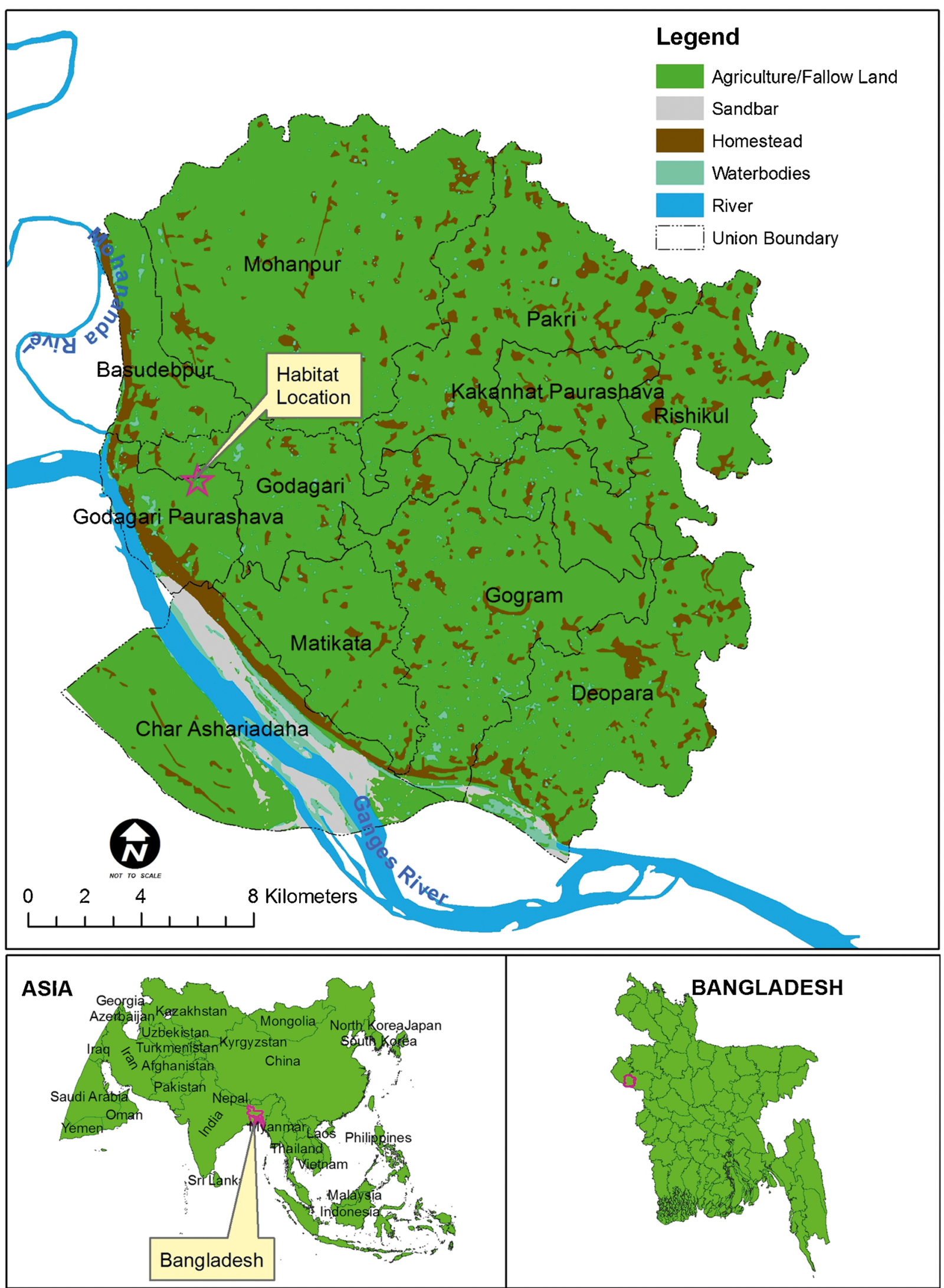

Map 1. Current location of Eulophia obtusa at Godagari, Rajshahi, Bangladesh. 


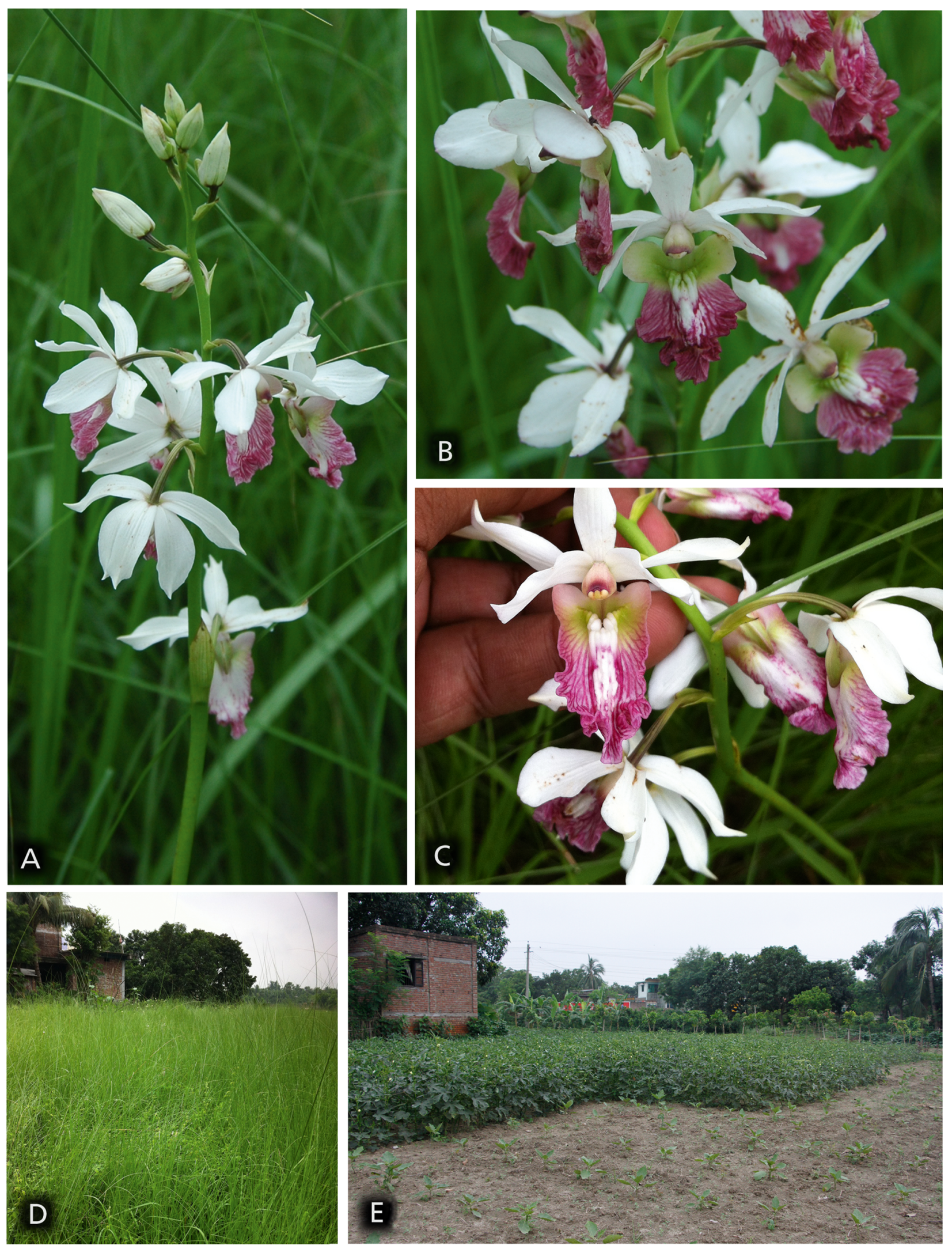

Fig. 1. Eulophia obtusa. A plant in habitat; B flowers; C close-up showing spur and callus; D habitat in $2014 ;$ E habitat in 2015. PHOTOS: M. S. H. SOURAV. 
Oudh, at Chandanpur in the Gonda district, Duthie's collector s.n. (n.v.)

Terrestrial, seasonally deciduous herb, bearing underground corms. Corm white, dome-shaped, $2.5-3.1 \mathrm{~cm}$ wide and $3.3-5.5 \mathrm{~cm}$ high, lying $10-20 \mathrm{~cm}$ below ground, bearing vermiform, white roots. Shoots $1-5$ leaved, usually bifoliate, basal part formed by sheaths enveloping the base of the inflorescence as well as the leaf-bases. Leaves appearing with the inflorescence, grass-like, $35-50 \mathrm{~cm}$ long, $0.15-0.5 \mathrm{~cm}$ wide, linear, slightly plicate, apex acuminate, midrib prominent, sheathing at base. Inflorescence erect, $40-60 \mathrm{~cm}$ tall; peduncle terete with a few distant, c. $5 \mathrm{~cm}$ long, lineartriangular, sterile bracts; rachis up to c. $10 \mathrm{~cm}$ long, bearing 4 - 12 flowers usually opening simultaneously and more or less evenly spaced. Flower $3-4 \mathrm{~cm}$ diam.; sepals and petals white, lip white tinged pink, with numerous deeper purplish pink, branching veins, zone surrounding the mouth of the spur light green; calli white, green in the basal part of the lip; spur green; column creamy white, apex red-purple, anther yellowish tinged green, with faint purple markings. Floral bracts c. $1.4 \mathrm{~cm}$ long, lanceolate, acuminate, much shorter than the combined length of pedicel and ovary. Pedicel with ovary c. $24 \mathrm{~mm}$ long, curved, glabrous, terete, ovary ribbed. Dorsal sepal c. $2.0 \times 0.5$ cm, oblong-lanceolate, acute, 7-nerved; lateral sepals similar, c. $1.8 \times 0.5 \mathrm{~cm}$. Petals $1.8 \times 0.6 \mathrm{~cm}$, oblonglanceolate, obtuse. Lip $2.1 \times 1.7 \mathrm{~cm}$ when flattened, at right angles to the column, 3-lobed; lateral lobes basal, erect, c. $5 \times 4 \mathrm{~mm}$, semi-elliptic, rounded; midlobe c. $1.7 \times 1.3 \mathrm{~cm}$, elliptic, almost truncate, margins undulate; callus complex, consisting of 3-4 short, transverse ribs on either side of the mouth of the spur, and 5 longitudinal ribs of unequal size and height occupying most of the median part of the midlobe; veins thickened; spur c. $6.7 \mathrm{~mm}$ long, conico-cylindrical, obtuse, curved forward and appressed on the abaxial surface of the labellum. Column $8 \mathrm{~mm}$ long, with short foot. Fruit not seen. (Description based on material from Bangladesh only). (Fig. 1).

DISTRIBUTION. Northwest India (Uttarakhand, Uttar Pradesh, ?Assam, ?Chhattisgarh), ?Nepal, Bangladesh. SPECIMENS EXAMINED. INDIA: Uttarakhand, Dehra Dun, Karwapáni Swamp, 22 July 1899, P. W. Mackinnon 22722 (K!; probably one of the syntypes of Eulophia campanulata); Uttar Pradesh, Upper Gangetic Plain, Pilibhit, Bargadbhanki, 24 June 1902, Inayat 25796 (K!).

BANGLADESH: Rajshahi, Godagari, 27 June 2014, M. S. H. Sourav 09 (DACB!). Also reported from Assam (Dutta \& Sarma 2013) and Nepal (Rajbhandari \& Dahal 2004; Rokaya et al. 2013); we have seen no material from there, and these records require confirmation.
HABITAT. The only known site of Eulophia obtusa in Bangladesh is situated in the high Barind tract, one of the major agro-ecological regions comprising about $79 \%$ of Godagari upazila. The area lies at about $15 \mathrm{~m}$ above sea level, and is not normally flooded, although the grassland in which the orchid occurred was usually water-logged during the peak of the rainy season. The vegetation is composed of grasses like Imperata cylindrica and Saccharum spontaneum as well as herbs and shrubs, including Amorphophallus margaritifer, A. paeoniifolius, Boerhavia diffusa, Chrozophora rottleri, Colocasia esculenta, Commelina benghalensis, Croton bonplandianus, Cyanotis cristata, Cyperus sp., Digera muricata, Euphorbia hirta, Ficus hispida, Kyllinga microcephala, Leucas lavandulifolia, Lippia alba, Parthenium hysterophorus, Phyllanthus virgatus, Solanum villosum, Uraria picta, and others. In North India, Eulophia obtusa has been found in freshwater swamps (Deva \& Naithani 1986). The elevations have not been recorded for the collections we have seen, but they are probably all from below $200 \mathrm{~m}$ asl.

PHENOLOGY. Flowering: June - July; fruiting: not seen, but local informants stated that they had seen the plants in fruit.

NOTES. An unpublished painting from 9 July 1900 in the Icones collection of Kew by $\mathrm{H}$. Hormusji of an orchid collected in the Raipur District of Central India (Chhattisgarh) and grown by J. Martin represents a taxon that is strikingly similar to the Bangladesh form of E. obtusa in colour, except that it lacks the green tinge in the basal part of the lip. It differs in the much simpler callus structure: instead of a series of small transverse calli along the mouth of the spur there are just two large, wing-shaped, undulate calli, which are connected to three (not five) lamellae on the midlobe. Since the artist also drew the column, anther and pollinarium in great detail, we do not think that the simpler callus structure is due to a superficial and inaccurate representation. If this painting represents a form of E. obtusa, then it is evidence for a considerable range extension towards the South. The painting had been annotated as "Eulophia n. sp." by R. A. Rolfe.

It should be noted that Duthie (1906) claimed that the collecting locality of Eulophia obtusa as cited by Lindley refers to that of a specimen of E. flava (Lindl.) Hook. f. There are no locality data on the type sheet of E. obtusa, and we do not know on what grounds Duthie made his claim.

\section{Taxonomic notes}

Eulophia campanulata was described as having bright yellow sepals and petals, with incompletely reported colours of the lip. A partially hand-coloured copy of Duthie's plate (1906: t. 111) in the Icones collection at Kew shows a creamy-white lip with a bright yellow apical half of the mid-lobe, with purple suffusion at 
the base, and with a fine, irregular, transverse purple line halfway the mid-lobe, separating the bright yellow from the cream-coloured part. This species was synonymised with E. obtusa by Duthie himself (1906). There is a painting of a Falconer specimen at Kew (Falconer 46), lacking locality data, which also has yellow flowers, with hardly any purple on the lip. The colours of the type collection of E. obtusa were not recorded, therefore we do not know if the strikingly different colours of our Bangladesh specimens are unusual for the species. Since some species of Eulophia can be quite variable in flower colour, and because the morphology of our Bangladesh material agrees very well with the type of E. obtusa, we do not doubt our identification. The painting by Hormusji mentioned above, if interpreted as representing E. obtusa, suggests that the white-and-purple form also occurs in India.

Eulophia obtusa is quite different in floral morphology from all other Asian species of Eulophia, except E. explanata Lindl. That species, however, is easily distinguished by the hardly developed spur, the different callus structure on the lip, and the much broader, elliptic leaves. In addition, the flowers of E. explanata are only about half the size of those of E. obtusa. E. obtusa also resembles some tropical African species, especially E. cristata (Sw.) Steud. and E. livingstoneana (Rchb. f.) Summerh. It remains to be seen if the similarity is due to a close relationship or convergent evolution.

\section{Population and conservation}

During the first author's visit in June 2014, about 20 mature flowering individuals were observed in an area of about 0.8 hectares, but due to the tall and dense vegetation it was difficult to find the specimens. Undoubtedly many were missed, especially the ones that were not in flower. Another visit was conducted during August 2014 for fruit collecting, but this failed, as it proved impossible to find the plants without flowers; the grasses had become even taller than before. The next field trip took place in May and June 2015. Sadly, by then the whole habitat had been destroyed and the grassland converted into agricultural fields (Fig. 1E) using ox-ploughing. Local farmers had planted Okra (Abelmoschus esculentus) and Brinjal (Solanum melongena). Through interviews with the locals we learned that around 7 to $10 \mathrm{kgs}$ of orchid corm had been destroyed and there had been approximately 500 individuals in the area. One informant claimed that he had seen new plants coming up from the cultivated ground and indeed, after a thorough search, the first author counted around 310 vegetative shoots in this agricultural field. We assume that hundreds of the orchid corms were lost by exposure to direct sunlight due to overturning of the soil for cultivation of vegetables.
Many species of Eulophia (e.g. E. dabia (D. Don) Hochr., E. graminea Lindl., E. herbacea Lindl.) are usually found in open grasslands (Deva \& Naithani 1986), and it would seem that for E. obtusa, such grasslands are even the sole habitat. Destruction of these uncultivated grasslands will certainly lead to local extinction of some of these species. For the time being the first author has taken immediate conservation action by fencing off the areas where plants remain, with the consent of the land owner and the local community. It remains to be seen if E. obtusa will be able to survive here in the longer term. We hope that steps towards ex-situ conservation can be undertaken in the near future.

\section{Conservation status}

Orchids are often the victims of habitat loss, degradation and fragmentation, as well as unsustainable collecting. In Bangladesh, Eulophia obtusa is clearly under serious threat due to habitat loss and reduction in the number of mature individuals. This species was originally described from Uttarakhand in India (Lindley 1833); it has later been collected from the Gangetic plains by W. Bell, Mackinnon, Duthie and Inayat prior to about 1902 (Duthie 1915; Deva \& Naithani 1986; Jalal et al. 2008). Since then it has, to our knowledge, never been recorded from this region again. Deva \& Naithani (1986) stated, optimistically, that "a search in fresh water swamps at the base of Himalaya will definitely yield results." E. obtusa has also been recorded from Chirang Reserve Forest, Assam (Dutta \& Sarma 2013) and Nepal (Rajbhandari \& Dahal 2004; Rokaya et al. 2013), but it was listed as being of doubtful occurrence by Jalal (2012). Accepting the above-mentioned Hormusji painting as representing E. obtusa, the species has also been found in Central India (Chhattishgarh). At the time of writing there are no photographs of E. obtusa on the internet, which is a probably a good indication that it is indeed a rare species.

Without knowing the modern extent of occurrence in India (and possibly Nepal) it is not possible to provide a global assessment. The fact that it has not been collected in Uttarakhand, Uttar Pradesh, and possibly Chhattishgarh for over a hundred years suggests that it may well be an endangered species. For Bangladesh there is a decline in the number of mature individuals from 500 to 310 , i.e. a $38 \%$ loss, a severe degradation (if not a complete loss) of habitat, and a continued threat of uprooting of plants due to shifting agriculture. Based on the IUCN (2001) Red Listing criteria, the species can be assessed as Critically Endangered [B2ab(i,ii,iii,v)] in Bangladesh. Since it is possible that the population occurring in Bangladesh represents a unique and attractive colour form, its protection as a subject of potential horticultural value 
seems all the more urgent. It would be a great loss if this beautiful orchid were to disappear completely.

\section{Acknowledgements}

The first author expresses his deep gratitude to Prof. D. Sarma for his encouragement to study the flora of Bangladesh; to Mr J. M. Garg for his kind help in circulation of the orchid pictures through his google group, "efloraofindia", and to Mohammad Abdur Rashid for information on the Barind area and for the habitat location map. We thank two anonymous reviewers for valuable suggestions.

Open Access This article is distributed under the terms of the Creative Commons Attribution 4.0 International License (http://creativecommons.org/ licenses/by/4.0/), which permits unrestricted use, distribution, and reproduction in any medium, provided you give appropriate credit to the original author(s) and the source, provide a link to the Creative Commons license, and indicate if changes were made.

\section{References}

Bone, R. E., Cribb, P. J. \& Buerki, S. (2015). Phylogenetics of Eulophiinae (Orchidaceae: Epidendroideae): evolutionary patterns and implications for generic delimitation. Bot. J. Linn. Soc. 179: $43-56$.

Chase, M. W., Cameron, K. M., Freudenstein, J. V., Pridgeon, A. M., Salazar, G., Van den Berg, C. \& Schuiteman, A. (2015). An updated classification of Orchidaceae. Bot. J. Linn. Soc. 177: 151 - 174.

Deva, S. \& Naithani, H. B. (1986). The Orchid Flora of North-west Himalaya. Print and Media Associates, New Delhi.

Duthie, J. F. (1902). Descriptions of some new species of Orchideae from North-West and Central India. J. Asiat. Soc. Bengal, Pt. 2, Nat. Hist. 71: $37-45$. (1906). The Orchids of North-western Himalaya. Ann. Roy. Bot. Gard. (Calcutta) 9 (2): 1 - 211.
(1915). Flora of the Upper Gangetic Plain and of the adjacent Siwalik and Sub-Himalayan Tracts, Volume 3. The Superintendent of Government Printing, Calcutta.

Dutta, S. U. \& Sarma, G. C. (2013). Orchid diversity at the Chirang Reserve Forest of BTAD, Assam. Global Research Analysis 2 (5): 9 - 10.

Govaerts, R., Campacci, M. A., Baptista, D. H., Cribb, P. J., George, A., Kreutz, K. \& Wood, J. J. (2016). World checklist of Orchidaceae. The Board of Trustees of the Royal Botanic Gardens, Kew. Available from: http:/ /apps.kew.org/wcsp/Retrieved (accessed 13 February 2016).

Hooker, J. D. (1890). The Flora of British India, Vol. 6. L. Reeve \& Co, London.

IUCN (2001). IUCN Red List Categories and Criteria: Version 3.1. IUCN Species Survival Commission. IUCN, Gland and Cambridge.

Jalal, J. S. (2012). Status, threats and conservation strategies for orchids of western Himalaya, India. J. Threatened Taxa 4 (15): 3401 - 3409.

, Kumar, P., Rawat, G. S. \& Pangtey, Y. P. S. (2008). Orchidaceae in Uttarakhand, Western Himalaya, India. Checklist 4 (3): $304-320$.

Kuntze, O. (1891). Revisio generum plantarum 2. A. Felix, Leipzig,

Lindley, J. (1833). The genera and species of orchidaceous plants. J. Ridgway \& sons, London.

Martos, F., Johnson, S. D., Peter, C. I. \& Bytebier, B. (2014). A molecular phylogeny reveals paraphyly of the large genus Eulophia (Orchidaceae): A case for the reinstatement of Orthochilus. Taxon 63 (1): 9 23.

Pridgeon, A. M., Cribb, P. J., Chase, M. W. \& Rasmussen, F. N. (2009). Genera Orchidacearum, vol. 5. Epidendroideae (Part two). Oxford University Press, Oxford.

Rajbhandari, K. R. \& Dahal, S. (2004). Orchids of Nepal: a checklist. Bot. Orient. 4: 89 - 106.

Rokaya, M. B., Raskoti, B. B., Timsina, B. \& Münzbergová, Z. (2013). An annotated checklist of the orchids of Nepal. Nordic J. Bot. 31: $511-550$.

Schlechter, R. (1919). Orchideologiae Sino-Japonicae Prodromus. Repert. Spec. Nov. Regni Veg. Beih. 4: 1 - 319. 